\title{
Tributary Activities of Vietnam and Korea with China: Similarities and Differences*
}

Although Korea is in Northeast Asia and Vietnam is in Southeast Asia, due to similarities in historical circumstances and being deeply influenced by Chinese civilization, the two countries share many similarities. Foremost among these similarities is the diplomatic aspect, which most clearly reflects the close relationship between geopolitics and behavior with the outside world. If East Asian modern history (including Vietnam and Korea) is the history of relations with the West, then East Asian premodern history is the history of relations with China. Therefore, comparing the Chinese tributary activities of Korea with the diplomacy of Vietnam in the medieval period not only shows similarities and differences in diplomacy between the two countries but also helps to determine the position and behavior of Vietnam and Korea with China as the center of the East Asian regional order at that time.

* This research is funded by the Vietnam National Foundation for Science and Technology Development (NAFOSTED) under grant number 601.01-2019.01

** Hanoi National University of Education, 136 Xuan Thuy Street, Cau Giay District, Hanoi, Vietnam, myhanhvnh@gmail.com 


\section{Research Content}

In Vietnam, the earliest document about Korea is the Bắc sủ thông luc (Complete History of the North) written by the Vietnamese historian Le Quy Don who lived in the eighteenth century. In this book, Korea was referred to as "the Eastern Country" 东国 or "the country in the East." Later, in another book called Kiến văn tiểu lục (Picking up what eyes see and ears hear) by Le Quy Don, Korea was mentioned many times by the name Cao Ly country. According to Le Quy Don: "The Cao Ly country, in the Tang dynasty, was called An Đông đô hô phủ (Protectorate General to Pacify the East (Chinese: 安东都 护府), until Wang Kŏn (王建, 918-943) restored and established a country that included (former) Silla and Paekje." The word "Cao Ly" was transcribed in Italian as "Cauli," in English as "Corea," and it is now transcribed as "Korea." In 1392, Cao Ly collapsed and was replaced by the Chosŏn Dynasty (1392-1897) and later the Great Han Empire (1897-1910) (대한제국, 大韓帝國, Taehan Cheguk) before being annexed by Japan in 1910. From 1948 to the present, the peninsula was split into two countries: Daehan Minguk (대한민 국, 大韓民國, the Republic of Korea) and Chosŏn Minjujuŭi Inmin Konghwaguk (조선 민주주의 인민 공화국, 朝鮮民主主義人民共和國, Democratic People's Republic of Korea.) Therefore, referring to Korea in the pre-modernpre-modern period means North Korea and South Korea collectively now.

\section{The Similarities in the Reasons for Chinese Tribute of Vietnam and Korea}

One of the common traits found in the diplomacy of the two countries

1 Le Quy Don, Lê Quý Đôn toàn tập (Le Quy Don Works in Full), translated and annotated by Pham Trong Diem Vol.4 (Hanoi: Social Sciences Publishing House, 1997), 223-224. 
during the pre-modern period is diplomatic relationships with China. This is primarily due to geography since both Vietnam and Korea share borders with China. There is no sea barrier like with Japan. If Vietnam is bordered by China in the southeast, Korea is bordered by China in the northeast. Despite many periods of peaceful diplomacy with China, there were many wars during pre-modern times due to China's ambition to invade the territory of neighboring countries. For example, Sui China mobilized a large number of troops and launched a war against Korea (Koguryŏ, $37 \mathrm{BC}$ to $668 \mathrm{AD}$ ). However, the people of Korea were united, and they were able to repel the Chinese aggressors. In 612, Sui troops invaded Korea again, but Korean forces fought bravely and destroyed the Sui. ${ }^{2}$ Or while the Tran dynasty (Vietnam) defeated the Mongol - Yuan army three times $(1258,1285,1288)$, in 30 years from 1231 to 1259 , Korea also had seven battles against China. ${ }^{3}$ While the Tay Son dynasty defeated the Qing army in 1789 during the most prosperous time of the dynasty, Korea had two battles against the Qing army in 1627 and $1636 .{ }^{4}$ By comparison, the wars that China created with Vietnam were always fiercer and more frequent. However, in terms of time, the combined years at war between Vietnam, Korea and China is much shorter than the number of years of peaceful diplomacy among the countries engaging in tributary activities.

2 Andrew C. Nahm, A Panorama of 5000 Years: Korean History (Second revised ed.) (Seoul: Hollym International Corporation, 2005), 18; Yi Kibaek, A New History of Korea (Harvard University Press, 1984), 47; Michael J. Seth, A History of Korea: From Antiquity to the Present, (Landham, Md.: Rowman \& Littlefield, 2011), 112; Kim Djunkil, The History of Korea (Second-ed.) (Santa Barbara, California: ABC-CLIO, 2014), 65-68.

3 Kenneth B. Lee, Korea and East Asia: The Story of a Phoenix. Westport (CT: Greenwood Publishing Group, 1997), 72; Lee Hyunhee, Park Sungsoo, and Yoon Naehyun, New History of Korea (Paju: Jimoondang, 2005), 343-350; Association of Korean History Teachers. Korea Through the Ages, Vol 1 Ancient. (Seoul: Academy of Korean Studies, 2005), 142-145.

4 Kim Haboush Jahyuun, The Great East Asian War and the Birth of the Korean Nation (New York: Columbia University Press, 2016), ix. 
With a geographic location bordering China, both Korea and Vietnam in the medieval ages were classified as the "Chinese cultural sphere." ${ }^{5}$ If we divide the neighboring countries surrounding China at this time into two concentric circles, the first round adjacent with the Huaxia center included BaiYue (百越/百粤) in the south, Beidi (北狄) in the north, and Xirong (西戎) in the West. The second outer ring included countries influenced by the Han civilization, such as Japan, Korea, and Vietnam. ${ }^{6}$ Accordingly, during the two thousand years before European powers arrived on the continent in the middle of the nineteenth century, the relations between Vietnam-China and Korea-China were limited within the framework of the East Asian model. In this model normality was recognized by the parties and characterized by relations that revolved around China with different social communities set at varying levels depending on Beijing (or on relations with Beijing) or on autonomous independence compared to Beijing. ${ }^{7}$ The book Wei Liang and Faizullah Khilji in China and East Asia's Post - Crisis Community: A region in Flux also affirms this: "China, the primus inter pares state in this tribute system, constituted the core together with Japan, Korea, and Vietnam, with the system extending to the Southeast Asian States in varying degrees." ${ }^{\text {Therefore, in }}$ terms of form, Vietnam and Korea in the pre-modern period were the vassals around the Han civilization. The order was established and maintained during pre-modern times based on tributary relations in which the

5 The Chinese cultural sphere was formed around the beginning of the Christian era with the boom of the Han Empire, one of the two most powerful empires in the world at that time, besides the Roman empire in the Mediterranean (from the 1st century to the 5 th century AD.

6 Ngo Duc Thinh, "Lý thuyết trung tâm và ngoại vi trong nghiên cứu không gian văn hóa (Central and Peripheral Theory in Researching Cultural Space)," Journal of Social Science Information, Hanoi No. 3 (2014): 16.

7 Samuel P. Huntington, The Clash of Civilizations and the Remaking of World Order (New York: Simon \& Schuster, 1996), 234.

8 Wei Liang \& Faizullah Khilji, China and East Asia's Post-Crisis Community: A region in Flux. (Lexington Books, 2012), 2. 
Chinese emperor acknowledged the surrounding countries, and countries such as Vietnam and Korea declared themselves vassals and paid tribute.

In fact, a Chinese-style world order that was based on tribute as its core could not exist if it was a unilateral Chinese ideology. Instead, it had to be established based on approval from both parties, including China and its vassals. On the one hand, this was a concession of the weaker countries to China's ambitions to expand and invade. On the other hand, standing in this world order is essentially an acknowledgement of the practical advantages in Chinese politics and culture. ${ }^{9}$ At that time, the pre-modern courts in Vietnam and Korea realized that China was the most civilized country to learn from. In the eyes of its vassals, China was the origin of the Chinese cultural sphere (also known as the cultural area of Chinese characters) and from China, the Chinese character culture with its deep imprint of Confucianism spread to surrounding East Asian countries. This expansion created conditions to promote the stronger development of civilization throughout the region. This development explains why countries such as Vietnam and Korea considered Chinese politics and culture as a model to study at that time and applied it to building a centralized pre-modern political system that used Confucianism as an ideological foundation. The thought of "no difference, no inferiority to China." 10 appeared in Vietnam; and the concept of "to live outside the realm of Chinese culture was, for the Korean elite, to live as a barbarian" ${ }^{11}$ in Ko-

9 Yu Insun, "Lịch sử quan hệ triều cống Việt Nam - Trung Quốc thế kỷ XIX. Thể chế triều cống, thực và hư (History of Vietnam - China relations in the nineteenth century: Tributary institutions, truths and wrongs)", Historical Studies, Hanoi, 9 (2009): 20.

10 Tran Quoc Tran, "Suy nghĩ đôi điều về văn hóa Việt Nam (Trong sự đối sánh với văn hóa Trung Quốc (Something About Vietnamese Culture (In comparison with Chinese culture)" in Vietnamese Culture to be Explored and Pondered (Literature Publishing House, 2003), 57.

11 Kim Samuel, "The Evolving Asian System: Three Transformations," in International Relations of Asia, ed. David Shambaugh and Michael Yahuda (Maryland: Rowman \& Littlefield Publishers, 2008), 38-39. 
rea emerged.

Since then, the pre-modern dynasties of Vietnam, as well as Korea, embraced Confucian thought and the administrative - social organization of China, taking them as their models. At the same time, there was no other model, and the core principles of Confucianism, such as Decorum and Righteousness, reappeared, thus creating a connection between the vassal states and the Chinese "Celestial Empire." Vassals were urged to behave diplomatically with the "Celestial Empire" in accordance with the propriety and regulations according to their position. It can be said that thanks to these core thoughts, China imposed a tributary system and maintained it, making countries such as Vietnam and Korea participate in the system.

\section{Tributary Frequency and The Position of Vietnam and Korea in the Chinese Tributary System}

To ensure the ordination request activities and to maintain peaceful diplomatic relations with China, the pre-modern courts of Vietnam and Korea also sent Chinese tribute periodically. The book repository of the Qing Dynasty shows the formation of a complete tributary system for the vassals of the Qing Dynasty. Accordingly, the tributary frequency for Korea was once a year, every two years for the Ryukyu Kingdom (now Okinawa), every three years for An Nam (Vietnam), every four years for Siam (Thailand), every five years for Sulu (South Philippines), and every ten years for Burma (Myanmar) and Laos. ${ }^{12}$ Obviously, compared with Vietnam, the tributary frequency of Korea was greater. If importance is based on the rule of tributary frequency mentioned above, then it is clear

12 Tran Nam Tien, "Văn hóa ứng xử của Việt Nam trong quan hệ với Trung Quốc thời trung đại- Nhìn từ hoạt động sắc phong và triều cống (Vietnam's Behavioral Culture in Relations with China in the Medieval Ages - Considered from the "Ordination and tribute)," Science \& Technology Development, 15, No.X1 (2012): 63. 
that Korea and then Vietnam were the two most important vassals and the two most favored neighboring countries. The Hongwu emperor (朱元璋 주원장) in the Ming Dynasty once declared, "I am the ruler of the world officially, from now on, every three years, overseas countries enter to pay tribute, An Nam (安南 안남) takes the lead, then to Cao Ly (高麗 고려), after that to Chiem Thanh (占城 점성), all countries have to declare themselves vassals according to ancient regulations, I really appreciate that." 13 A great official of the Ming Dynasty, Vuong Ngao (王鏊 왕오) further emphasized this, "All countries influenced by the mighty virtue of China have the opportunity to pay tribute every year. Korea and An Nam are two countries that are close and have a close relationship with China, having culture and decorum so that the Chinese court will give the most favor to these two countries. ${ }^{14}$

However, the degree of intimacy with the "Celestial Empire" as well as the position of each country in the tributary system of China was not the same. Due to the impact of geopolitical characteristics, the relationship between Korea and China was somewhat closer. Korea frequently provided support to China in the fight against piracy. From 1401 to 1455, for example, Korea provided the Ming dynasty with intelligence on piracy 12 times. ${ }^{15}$ Korea used to act as an intermediary for China to dispatch envoys to Japan. Even in 1645, when asking Korean envoys to take some of the Japanese who had drifted by sea to China back to their country, the Qing dynasty tried to ask Korea to act as a bridge to restore relations between the two countries. ${ }^{16}$ This never happened in relations between Vi-

13 Tran Quang Duc, Tưong đồng quan phục ba nước Trung Quốc Việt Nam - Hàn Quốx (Similarities in mandarin attire of the three countries China - Vietnam - Korea), 2013. https://nghiencuulichsu.com/2013/12/12/tuong-dong-quan-phuc-banuoc-trung-quoc-viet-nam-va-han-quoc/

14 Tran Quang Duc, Tưong đồng quan phục ba nước Trung Quốc Việt Nam - Hàn Quốx.

15 Dan Ton Nai, 中日关系史, 社会科学文献出版社, 北京 (History of SinoJapanese Relations) Vol. I. (Beijing: Social Sciences Academic Press, 2006), 243.

16 Manh Hieu Huc, “1644 年日本越前人的 “鞑䩗漂流”与清初中日关系 (The 
etnam and China in pre-modern times. Although Korean assistance failed to prevent China-Japan relations from entering a period of "freezing" in the early eighteenth century, ${ }^{17}$ it partly showed the mutual relationship between China as the suzerain and Korea as a vassal. In particular, at the end of the sixteenth century, when the Nham Thin Oa loan (Imjin waeran, 1592 and 1598) wars broke out, Japan ordered an attack on Korea. The Chosŏn army received help and support from the Ming army to expel the Japanese army from the peninsula, ending the 7-year war. Obviously, in the relationship with Korea, the responsibility of China as the "suzerain country" was shown quite clearly.

If considering the order of the vassals in the world order with China as the center, Vietnam was usually ranked behind Korea. Therefore, when entering the court to meet the Chinese emperor, the Korean envoys often stood above the Dai Viet envoys. Yi Sukwang, the Korean envoy, clearly affirmed, "When entering to pay tribute, our country's envoy stands first, and the An Nam envoy stands behind. There is mutual respect in communication." 18 The high-low-order distinction was not only shown in diplomatic etiquette but also evident in the gifts from the "Celestial Empire." As usual, the kings of An Nam or Korea were often given robes and hats through envoys. If the King of Chosŏn was given an "imperial robe and royal crown" (the emperor's outfit) as a real king, the King of An Nam was only granted the costume of a normal servant. However, in terms of

Japanese people "wandering to Tac ta" before 1644 and Sino-Japanese Relations in the early period of Qing dynasty," Teaching History, No. 2 (2008): 12.

17 Manh Hieu Huc, “1644 年日本越前人的 “鞑䩗漂流”与清初中日关系 (The Japanese people "wandering to Tac ta" before 1644 and Sino-Japanese Relations in the early period of Qing dynasty," 13.

18 Nguyen Thanh Tung, Peaceful communication and competition: about the reunion between the Dai Viet envoys and Chosón envoys in China in 1766-1767, "International Conference on Vietnam - Korea Relationship in the past, the present and the future (2012)" held by University of Social Sciences and Humanities, Ho Chi Minh City under the sponsorship of the Academy of Korean Studies. 
titles, he was still accorded the title of "King" like the King of Korea. ${ }^{19}$

Therefore, competition and the pursuit of equality between the vassals arose, Vietnam and Korea being no exception. In many conversations between the envoys of Vietnam and Korea visiting China, the envoy of Vietnam, as well as the envoy of Korea, expressed this sentiment of equality and competition. For example, the meeting between the envoy Nguyen Huy Oanh and the Korean envoy in China in 1766, in addition to efforts to find a joint agreement between the two countries in the same situation, both parties clearly showed a sense of national pride. In a poem Sending Cao Ly, Nguyen Huy Oanh wrote:

This universe embraces all

We should self-improve our morality

Tang of Shang is your long-standing ancestor

The Yan Emperor is my ancestor

Big and small islands are divided into countries

But all under this same starry sky

When we want to greet each other

Having to rely on an interpreter

It is known that the previous envoys came here

Acknowledged as benevolent people in your country

They had a profound understanding of literature

As well as human love

I am so lucky to meet you here

Sincerely I send you a poem. ${ }^{20}$

Obviously, through verses such as "Tang of Shang is your longstanding ancestor / The Yan Emperor is my ancestor / Big and small is-

19 Nguyen Huy Vinh ed, Thạc Đình di cảo (Thac Dinh posthumous manuscript), Vietnam Library of Institute of Sino-Nom studies, symbol A.3135, sheet 87a, 2006, 174-175.

20 Nguyen Huy Vinh, Thạc Đình di cảo. 
lands are divided into countries," Nguyen Huy Oanh indirectly emphasized Vietnam's position, sovereignty, and its own cultural history as a nation in comparison with Korea.

Also, during this envoy trip, Nguyen Huy Oanh proposed allowing the envoys of Dai Viet and Chosŏn to meet the Qing emperor on the same day. He recorded this in his diary, "On the 23rd day, going to appear. On the 29th day, going to the Court of State Ceremonies (鴻臚寺) for the ritual rehearsal. We (the envoys) proposed to join in the tribute with the envoys of Cao Ly. An official of the Ministry of Rites agreed and informed, 'Please wait for royal decree."' As a result, the Qing dynasty accepted, and the envoys of Vietnam and Korea then met with the Qing emperor on the 1st of the Lunar New Year in 1767. The envoy delegation of both countries was arranged to stand on the same level when meeting the king. This was considered a diplomatic victory for Vietnam in its attempt to assert its equal position with other vassals in the same tribute order for which China was the center. Korea was also always conscious of its competitive position with other countries. ${ }^{21}$ In a statement the Korean envoy Yi Sukwang said, "When entering to pay tribute, our country's envoy stands first, and An Nam envoy stands behind." This statement expressed pride in the position of his country. It also expresses the sense of defending national honor and appearance that is required of diplomats at all times.

\section{The Similarity in the Selection of Envoys for Ordination Requests and Tribute}

One of the indispensable requests of Vietnamese and Korean diplomats was to have a deep understanding of Chinese poetry and they subsequently made it a flexible tool to communicate with other diplomats. Obviously,

21 Nguyen Dynasty's National Historian Office. Đại Nam thục luc (True records of Đại Nam), Vol. V, Hanoi: Education Publishing House, 2007, 834. 
those diplomats must first be Confucian gentlemen and familiar with the proper style of poetry, letters, item, and music." This means that they must have comprehensive cultural knowledge, not only mastering the culture of their country but also understanding the national history - the culture of the other party to reach harmony in the communication process. Therefore, when selecting envoys for the tribute trips to China, the Vietnamese and Korean pre-modern dynasties chose those diplomats who had a profound understanding of culture and had the ability to correspond using Chinese poetry. Later, in a decree issued in 1840, Minh Menh King stipulated that the envoys who went to the Qing Dynasty to pay tribute must be proficient at literature and language; if they were poor, they only received contempt from other countries. This is since these envoys not only had to correspond equally using Chinese poetry to the Qing officials but also had to participate in literary competitions with envoys of other vassal states. $^{22}$

\section{The Purpose of the Chinese Tributary Activities of Vietnam and Korea}

Japan's tribute activities in China were for commercial purposes and for economic relations, Japan's ordination and the tributary system became the commercial ordination system, ${ }^{23}$ making the interdependence of "barbarians" "around the center of Huaxia" shift toward an interest-based relationship. ${ }^{24}$ In contrast, the Chinese tributary relationship of Vietnam

22 Woodside, Vietnam and the Chinese Model: A Comparative Study of Vietnamese and Chinese Government in the First Half of the Nineteenth Century (Cambridge, Mass.: Harvard University Press, 1971), 115.

23 Kim Minh, “明朝对日本贸易政策的演变 (Development of the Ming Dynasty's Trade Policy Towards Japan)," Economic History, no. 3 (2007): 12.

24 Hach Tuong Man, 朝贡 体系的建构与解构 - 另眼相 看中日关系史 (The Establishment and Disintegration of the Tributary System - A Different Perspective on History of Sino-Japanese Relations) (Wuhan: Hubei People's Publishing House, 
and Korea was more for political rather than economic purposes. It was considered to be a method of diplomacy to maintain peaceful relations as well as to ensure the dynasty's legitimacy for the people of the country as well as the people of neighboring countries. Therefore, Korea and Vietnam were the two most typical tributary countries in the Chinese tributary system. Even the ruling Confucian class in Korea considered participation in the tributary system as a basis for measuring the level of "civilization" of the nation. If they were outside the system, they would be considered "barbarians." 25 Therefore, this explains why the Chinese tributary system was maintained for so long in Korea and Vietnam. Until the early 1880 s, almost no Korean people considered their country to be equal or independent from China. ${ }^{26}$ In Vietnam, it was not until 1880 that the tributary activities ended with the last tribute trip led by Nguyen Thuat, Tran Khanh Tien, and Nguyen Hoan. ${ }^{27}$

\section{Substantial Independence in Tributary Relations of Vietnam and Korea with China in Pre-modern Times}

The sense of preserving national honor and appearances was not only reflected in the relationship among the vassals but also etched in the mind of the envoys of Vietnam and Korea in diplomatic relations with the Chinese. Therefore, it is no coincidence that when commenting on the Vietnam - China relationship in pre-modern times, a Japanese scholar Tsuboi admitted that, "The history of Vietnam is also the history of asserting

2008), 230.

25 Kim Samuel, "The Evolving Asian System: Three Transformations," in David Shambaugh and Michael Yahuda (eds). International Relations of Asia. (Maryland: Rowman \& Littlefield Publishers, 2008), 38-39

26 Kim Keyhuik, The Last Phase of the East Asian World Order (Berkeley: University of California Press, 1980), 341.

27 Nguyen Dynasty's National Historian Office, Đại Nam thục luc (True records of Đại Nam), Vol. VIII (Hanoi: Education Publishing House, 2007), 420. 
independence from China." ${ }^{28}$ This is because the thing hidden behind the nominal vassal declaration is a relentless effort to assert and maintain actual independence in relationships with China. Therefore, many times, the Vietnamese envoys frankly expressed their dissatisfaction with the disdain of Chinese dynasties they witnessed, considering them "barbarian envoys/ barbarian nation." ${ }^{29}$ Moreover, though the Vietnamese or Korean envoys kneeled before the Chinese emperor in Beijing as envoys of their "King," the heads of states still proclaimed themselves Emperor, on par with the suzerain Emperor to people in their country and other poorer neighboring countries. ${ }^{30}$ Not only that, if in relations with China Vietnam played the role of a vassal, in Vietnam's relationship with many Western and Southern countries at that time (such as Chenla - Cambodia, Van Tuong (a part of Central of Laos), bordering Nghe An north of Vietnam today), Nam Chuong (in the West of Hoa Binh province and in northern Thanh Hoa province of Vietnam today), Thuy Xa (in western Phu Yen province of Vietnam today), Hoa Xa (a tribe in the West of Thuy Xa, also in the West of Phu Yen province of Vietnam today), Vietnam was the suzerain. This stance is the realization of the thought of "no difference, no inferiority to China" of many Vietnamese pre-modern dynasties at that time. $^{31}$

28 Tsuboi Yoshiharu, Nước Đại Nam đối diện với Pháp vàTrung Hoa 1847-1885 (Dai Nam faced France and China from 1847-1885) (Hanoi: Vietnam Historical Society, 1992), 43.

29 Le Quy Don, Bắc sú thông lục (Complete History of the North), translated by Trinh Ngu (edited by Ngo The Long), handwritten document, symbols Bt.19 and Bt.85. Library of Institute of Sino-Nom studies, 2010.

30 Phan Huy Chu, Lịch triều hiến chuong loại chí (Records on Administrative Systems of Successive Dynasties), Vol.2. (Hanoi: Education Publishing House, 2007), 533.

31 Tran Quoc Vuong, "Tradition, Acculturation, Renovation: The Evolution Pattern of the Vietnamese Culture," in Southeast Asia in the 9th to the 14th Centuries, ed. David G. Marr, A. C. Milner. (Singapore: Institute for Southeast Asian Studies, 1988). 
Meanwhile, Korea, a vassal state considered to be the most revered and loyal to the Chinese ruling country, also repeatedly expressed hesitation with regard to requests from the Hongwu Emperor (the Ming dynasty) for the tribute of horses. Korea frequently did not comply with the Ming Dynasty's request because Korea also needed to stockpile horses for use in the event of a conflict with the Ming Dynasty in Manchuria. Furthermore, under the Qing dynasty, although continually paying tribute to the Chinese Emperor, Korean kings still despised the Qing Dynasty and deliberately kept the Ming Dynasty's calendar.

In addition, wars against the Mongols or the Qing where the Vietnamese and Korean courts tried to protect their borders and territorial integrity also vividly reflect the essence of independence in the suzerain-vassal relationship of between Vietnam, Korea and China in pre-modern times. According to the theory of Shils and Immanuel Wallerstein about the relationship between the center and periphery, besides the tendency of "dependence" of the periphery ("vassals") on the "center" (ruling country), there existed between them the tendency of "centrifugation," or "confrontation" due to the asymmetry of interests. This centrifugal tendency led to a shift in the position of Vietnam from being a "vassal" / "periphery" country depending on China to a "center" country in relations with smaller countries in Southeast Asia in the nineteenth century. ${ }^{32}$ Womack, a researcher specializing in Chinese national and international politics, described China as a "solid center." In comparison with other world powers, due to the great influence of Chinese Confucian culture on neighboring countries and the existence of a tributary system for centuries, "In contrast to the traditional West that had a 'liquid center - the Mediterranean-around and through which regimes swirled, China has been Asia's

32 Nguyen Thi My Hanh, "Hoạt động triều cống trong quan hệ ngoại giao giữa Việt Nam và các nước Đông Nam Á lục địa thế kỷ XIX (Tributary Activities in Diplomatic Relations Between Vietnam and Mainland Southeast Asian Countries in the Nineteenth Century)", Journal of Historical Studies, Hanoi, no. 3 (515), 2019, 12 30 . 
'solid center' of greatest productivity and population." ${ }^{33}$ But the relativity of power still was acknowledged in the relationship between the center and the periphery, the large and small countries because, according to him, the relationship was a disproportionate relationship of interests and the smaller countries themselves always felt "vulnerable." "If "If larger states are prudent, consultative, and cooperative, smaller states are less likely to be anxious about their vulnerability...(and) tend to accept the international order led by the larger state because it is inclusive of their interests." ${ }^{35}$

On the contrary, when big countries do not cooperate and threaten the interests of small countries and even injure the small countries, the tendency of dependence will become increasingly lax. The parties can even confront each other. Therefore, Womack also affirmed, "The key to a peaceful frontier did not lie in dominating neighbors, but rather in managing a mutually acceptable relationship." ${ }^{36}$ In addition, he pointed out that one of the other important reasons for the weakening of China's central position was the expansion of other peripheral relations around the center. ${ }^{37}$ Tributary relations between Vietnam, Korea, and China in the nineteenth century were no exception.

33 B. Womack, "Asymmetry and China's Tributary System," The Chinese Journal of International Politics 5 no. 1 (2012):39. https://doi.org/10.1093/cjip/pos003

34 B. Womack, "Asymmetry Theory and China's Concept of Multipolarity,” Journal of Contemporary China 13, no. 39 (May 2004):351-366. https://doi.org/10.114 2/9789814295284_0011

35 B. Womack, "Asymmetry Theory and China's Concept of Multipolarity," 351-366.

36 B. Womack, "Asymmetry and China's Tributary System," 42.

37 B. Womack, "Asymmetry and China's Tributary System," 44. 


\section{From the Position of "Vassals" in the Chinese-Centered Tributary System: Colonization after the Agreements Between the Qing Dynasty with France and Japan at the End of the Nineteenth Century}

In pre-modern times, if the King wanted to maintain the confidence of the people in his country, the King would have to train himself in accordance with the title, be worthy of Mandate of Heaventhe trust of God, otherwise he would be discarded by the people. ${ }^{38}$ Likewise, from a diplomatic perspective, a hierarchical suzerain-vassal relationship can only exist if both parties (the suzerain and the vassal) fulfill their duties properly (i.e. Legitimacy in Confucianism). It is a two-way relationship that interacts closely with each other. If either party gives up or fails to fulfill their responsibility according to the protocol, that system will gradually fade away and come to a breakdown. The relationship between Vietnam China and Korea - China in the second half of the nineteenth century proved that vividly.

In 1858, the French colonialists officially invaded Vietnam and imposed the yoke of domination on Vietnam. This not only threatened the survival of the Vietnamese nation but also directly threatened the political and economic interests of the Qing Dynasty in its role as "the ruling country." Moreover, the invasion of French colonialists in Vietnam also severely affected the border and territorial security of South China. Logically, asthe suzerain, China would have to be responsible for assisting its vassals in their struggle to protect national independence and territorial integrity. However, how did China behave as the suzerain enjoying political and economic benefits from a "vassal state" like Vietnam in the second half of the nineteenth century?

After the anti-French efforts when Hanoi (Vietnam) fell after the attack of Henri Riviere on April 25, 1882, Vietnam was unable to cope with the

38 Duong Thu Ai and Nguyen Kim Hanh, "Khổng Tủ với Luận ngũu" (Confucius with the the Analects) Hanoi: People's Public Security Publishing House, 2011. 
invasion of French colonialists and as a vassal state requested the assistance of China. On February 6, 1883, the Nguyen Dynasty officially dispatched a diplomatic delegation led by Pham Than Duat to China to ask for help from the Qing dynasty to cooperate against the French colonialists. However, as a result, during this trip, what the Nguyen Dynasty expected was not achieved from the Qing Dynasty. ${ }^{39}$ At the same time, during the time of the Nguyen Dynasty dispatching envoys to China to ask for aid, the French colonialists continued to frantically expand their war to the entire Red River delta area. In that context, with the consent of the Nguyen Dynasty, Nguyen Dynasty Counselor met the leader of the Qing army hoping to receive help. However, he also cleverly refused that the Qing country wanted to save Vietnam. But because the French cooperated with Li Hongzhang, the Qing dynasty could not support Vietnam. ${ }^{40}$ Next, the official of Bac Ninh province (Vietnam), Truong Quang Dan, went to Lang Giang to request the Rear admiral to send troops across the river to choose terrain to put pressure on the French. However, he also continued to refuse. In the end, King Tu Duc had to burst out disappointedly at the weak reaction and the indifferent attitude of the Qing army officers, saying, "In the end, we have to deal with our own affairs." 41

Meanwhile, the Qing dynasty sought to conciliate Liu Yongfu and the Black Flag army for the purpose of appropriating Vietnam from the French. ${ }^{42}$ On the other hand, China continued to order regular troops gar-

39 Trinh Nhu, Quan hệ Trung - Pháp về vấn đề Việt Nam cuối thế kỷ XIX (SinoFrench relations on Vietnam Issues at the End of the Nineteenth Century), (PhD diss., Hanoi National University, 1991), 75.

40 Nguyen Dynasty's National Historian Office. Đại Nam thục luc, Vol. VIII, 571.

41 Nguyen Dynasty's National Historian Office. Đai Nam thuc luc, Vol. VIII, 567.

42 The Black Flag army led by Liu Yongfu was originally a group of troops of the peasant uprising movement in Guangxi province in the 1950s and 1960s of the nineteenth century. Before the suppression of the Qing Dynasty, in 1865, Liu Yongfu took the Black Flag army across the border to the Cao Bang to submit the Hue court and it was used to suppress bandits in the uplands and mountainous areas bordering Vietnam - China. During their stay in Vietnam, the Black Flag army, 
risoned in Guangxi and Yunnan to massively cross the border, occupying the northern mountainous and midland provinces (of Vietnam) respectively. However, in fact, the Qing dynasty never dared to admit that the military presence was to help Vietnam fight against the French colonial invasion. Throughout 1882, the Qing army did not dare to directly confront the French militarily. On the contrary, they still negotiated with the French to resolve the problem of North Vietnam in their favor. The culmination of the France-China compromise was the Treaty of Tianjin signed on June 9, 1885, by the French representative Patenôtre and the representative the Qing Dynasty Li Hongzhang. In the treaty, China once again acknowledged the dominance of France in Vietnam and committed not to interfere in Vietnam, to respect present and future treaties, conventions, and agreements signed by France and Vietnam (Article 2 of the Treaty of Tianjin 1885) (Documents diplomatiques 1885). At this point, the presence of the Qing army within Vietnamese territory ended and the tributary relations between Vietnam and China terminated.

Meanwhile, in the second half of the nineteenth century, Korea fell into the same situation as Vietnam. The fate of Korea at that time was almost dependent on China. After China's defeat to the Japanese in 1895, the Qing Dynasty was forced to sign the Treaty of Shimonoseki, which was similar to the Treaty of Tianjin signed with France ten years previously by the Qing Dynasty. If the Treaty of Tianjin was the culmination of the Franco-Qing compromise on the Vietnam issue, the treaty of Shimonoseki can be considered the culmination of the Sino-Japanese compromise on the Korean issue. According to this treaty, China recognized Korean autonomy creating favorable conditions for Japan to act in Korea freely. Thus, with the Treaty of Shimonoseki, Korea was officially free from Chinese influence, allowing Japan to gain dominance over Korea. This is what China did to Vietnam in the Treaty of Tianjin in 1885. Obviously, under this circumstance, China did not fulfill its responsibility as the su-

together with the Vietnamese people and the Nguyen Dynasty army, achieved many victories, typically two victories at Cau Giay in 1873 and 1883. 
zerain. It abandoned its vassal states Vietnam and Korea in exchange for selfish interests through a series of agreements with the French colonialists and Japan in the second half of the nineteenth century.

Thus, at this time, the tributary relationship between China and Vietnam and Korea ended entirely and a new period in the diplomatic history of Vietnam and Korea began. Since then, Vietnam and Korea, from being a "vassal" state in the Chinese-centered world order have become colonies of the French and the Japanese.

\section{Conclusion}

Along with China and Japan, Vietnam and Korea were countries that belonged to the Confucian cultural space. Formed at the beginning of the Christian era with the development of the Han empire and the spread of Han culture, the Chinese cultural sphere attractred different countries into the same common culture marked by adopting Chinese characters for literacy, Chinese character-based literature, and Confucian thought as regional standards. Therefore, it is not surprising that Vietnam and Korea in pre-modern times had a special diplomatic relationship with China, the central cultural power. Thanks to its preeminence in terms of culture (particularly Confucian culture), China gained political dominance over other countries in the region, including Vietnam, Japan, Ryukyu, and Korea. If Ryukyu was considered an independent kingdom from Japan before 1879, it was clear that in pre-modern times, Vietnam, Japan, Ryukyu, and Korea all existed in a "tributary diplomacy" relationship with the Chinese suzerain. That relationship is also the realization of the hierarchical order according to the inherent decorum and regulations of Confucianism. This is especially true regarding Neo-Confucian thought with its principles of a hierarchical world order with the "big country" as the ruling suzerain and the small countries as "vassal states." However, due to the differences in geopolitics, Vietnam and Korea shared borders with China and were considered to be part of the Chinese cultural sphere, unlike Japan which was 
separated from China by a sea. Vietnam and Korea were located within the framework of an East Asian normative model. ${ }^{43}$ The levels of submission and tribute of these countries in their relations with China were not the same. While the political purpose was more dominant in the tributary activities of Vietnam and Korea, economic purposes dominated in the tributary activities of Japan and Ryukyu. In addition, while Vietnam, Korea, and Ryukyu were considered "vassal states" of the "ruling country" China, Japan was the only country in the "tributary system" that did not submit to China. This difference makes up its own characteristics in the Chinese tributary activities of each country.

In assessing and explaining the long-term existence of the tributary system between China and its neighboring countries such as Vietnam and Korea in a vassal position, Liam C. Kelley said, "Certainly, there is a logical reason why the outside countries accepted an inferior position in this relationship, which Western countries did not accept in the nineteenth century in diplomacy with China." In particular, he affirmed the abovementioned activities of Ordination request and tribute of Vietnam represented the "voluntary submission" rather than a "self-defense strategy." Therefore, these activities could not be "pretense" or "just appearance." Meanwhile, after Kelly, Fairbank and Teng, Taylor emphasized the duality in the nature of the tributary system and said that Vietnam did so based on a practical assessment of strategic interests, especially when Vietnam had to choose between agreeing to the unfair terms of the tributary system and the risk of attack from the center. ${ }^{45}$ Therefore, according to these scholars, the activities of these vassal states "pretended" to maintain inde-

43 Samuel P. Huntington, The Clash of Civilizations and the Remaking of World Order, 234.

44 Liam C. Kelly, Beyond the Bronze Pillars (Honolulu: University of Hawaiian Press, 2005), 9-13.

45 Truong Buu Lam, "Tribute in Sino-Vietnamese Relations, 1788-1790," in The Chinese World Order: Traditional China's Foreign Relations (Cambridge: Harvard University Press, 1968), 165-179. 
pendence, peace, avoiding bloodshed and war. ${ }^{46}$ Obviously, there are two almost contradictory opinions when evaluating tributary activities between the periphery countries and China. However, if we follow the progress of these activities, especially their specific movements in each historical period through the pre-modern dynasties of Vietnam and Korea, we can see that although there are strict regulations, the tribute of $\mathrm{Vi}$ etnam and Korea depended on the correlation of forces with China as well as on the potential and position of the two countries. ${ }^{47} \mathrm{I}$ think that if the act of submission of Vietnam and Korea towards China was voluntary, but not "pretending," then Vietnam and Korea would not have been able to take action to show independence as analyzed above. Obviously, here, there is no logic at all, just the forced survival behavior between the center and the peripheral countries in the context at that time. Such behavior is the wise behavior of small countries toward larger and stronger countries.

\section{References}

1. Association of Korean History Teachers. Korea Through the Ages, Vol. 1 Ancient. Seoul: Academy of Korean Studies, 2005.

2. Ai, Duong Thu and Hanh, Nguyen Kim. Khổng Tử với Luận ngũu (Confucius with the the Analects). Hanoi: People's Public Security Publishing House, 2011.

3. Chu, Phan Huy. Lịch triều hiến chuoong loại chí (Records on Administrative Systems of Successive Dynasties), Vol. 2. Hanoi: Education

46 Keith W. Taylor, "China and Vietnam: Looking for a New Version of an Old Relationship," in Jayne Werner \& Lưu Đoàn Huynh, The Vietnam War: American and Vietnamese Perspectives, (New York: M.E. Sharpe, 1993), 271.

47 Nguyen Thi My Hanh, "The issue of "ordination" in diplomatic relations between the Vietnamese pre-modern dynasties and China," Journal of International Studies 82 (September 2010): 25-40. 
Publishing House, 2007.

4. Dan, Ton Nai. 中日关系史, 社会科学文献出版社, 北京 (History of Sino-Japanese Relations) Vol. I. Beijing: Social Sciences Academic Press, 2006.

5. Documents diplomatiques. Affaires de Chine et du Tonkin 1884-1885. (China and Tonkin Affairs 1884-1885) Paris: Imprimerie nationale, 1885 .

6. Don, Le Quy. Lê Quý Đôn toàn tập (Le Quy Don Works in Full), translated and annotated by Phạm Trọng Điềm, Vol. 4. Hanoi: Social Sciences Publishing House, 1997, 223-224.

7. Don, Le Quy. Bắc sút thông lục (Complete History of the North), translated by Trinh Ngu (edited by Ngo The Long), handwritten document, symbols Bt.19 and Bt.85. Hanoi: Library of Institute of SinoNom studies, 2010.

8. Duc, Tran Quang. Tuơng đồng quan phục ba nuoóc Trung Quốc Việt Nam - Hàn Quốx (Similarities in mandarin attire of the three countries China - Vietnam - Korea), 2013. https://nghiencuulichsu.c om/2013/12/12/tuong-dong-quan-phuc-ba-nuoc-trung-quoc-vietnam-va-han-quoc/

9. Huc, Manh Hieu. “1644 年日本越前人的 “鞠䩗漂流” 与清初中日关系 (The Japanese people "wandering to Tac ta" before 1644 and SinoJapanese Relations in the early period of Qing dynasty." Teaching History, No. 2 (2008): 543.

10. Huntington, Samuel P. The Clash of Civilizations and the Remaking of World Order. New York: Simon \& Schuster, 1996.

11. Kim, Jahyuun Haboush. The Great East Asian War and the Birth of the Korean Nation. New York: Columbia University Press, 2016.

12. Kelley, Liam C. Beyond the Bronze Pillars. Honolulu: University of Hawaiian Press, 2005, 9-23.

13. Kim, Djunkil. The History of Korea (Second ed.). Santa Barbara, California: ABC-CLIO, 2014.

14. Kim, Keyhuik. The Last Phase of the East Asian World Order. Berkeley: University of California Press, 1980. 
15. Kim, Minh. “明朝对日本贸易政策的演变 (Development of the Ming Dynasty's Trade Policy Towards Japan).” Economic History, No. 3 (2007).

16. Kim, Samuel. "The Evolving Asian System: Three Transformations." in David Shambaugh and Michael Yahuda (eds). International Relations of Asia. Maryland: Rowman \& Littlefield Publishers, 2008.

17. Lam, Truong Buu. "Tribute in Sino-Vietnamese Relations, 17881790." in The Chinese World Order: Traditional China's Foreign Relations. Cambridge: Harvard University Press, 1968, 165-179.

18. Lee, Hyunhee, Park Sungsoo, and Yoon Naehyun. New History of Korea. Paju: Jimoondang, 2005.

19. Lee, Kenneth B. Korea and East Asia: The Story of a Phoenix. Westport. CT: Greenwood Publishing Group, 1997.

20. Man, Hach Tuong. 朝贡 体系的建构与解构 - 另眼相 看中日 关系史 (The Establishment and Disintegration of the Tributary System - A Different Perspective on History of Sino-Japanese Relations). Wuhan: Hubei People's Publishing House, 2008.

21. Nahm, Andrew C. A Panorama of 5000 Years: Korean History (Second revised ed.). Seoul: Hollym International Corporation, 2005

22. Nhu, Trinh. Quan hệ Trung - Pháp về vấn đề Việt Nam cuối thế kỷ XIX (Sino-French relations on Vietnam Issues at the End of the Nineteenth Century)., PhD diss., Hanoi National University, 1991.

23. Nguyen Dynasty's National Historian Office. Dại Nam thục luc (True records of Đại Nam), Vol. V, Hanoi: Education Publishing House, 2007.

24. Hanh, Nguyen Thi My. "Vấn đề "sách phong" trong quan hệ bang giao giữa các triều đại phong kiến Việt Nam với Trung Quốc.” ("The issue of "ordination" in diplomatic relations between the Vietnamese premodern dynasties and China) Journal of International Studies, No. 3 (82), September issue, Hanoi, 2010, 25 - 40.

25. Hanh, Nguyen Thi My. "Hoạt động triều cống trong quan hệ ngoại giao giữa Việt Nam và các nước Đông Nam Á lục địa thế kỷ XIX.” ("Tributary Activities in Diplomatic Relations Between Vietnam and 
Mainland Southeast Asian Countries in the Nineteenth Century") Journal of Historical Studies, Hanoi, No. 3 (515), 2019, 12-30.

27. Nguyen, Tran Van. "Consideration of offerings "Golden man replacing the real one" of An Nam in the Yuan - Ming Dynasties." Journal of Social Science, Shanghai, No. 6 (2006): 174-175.

28. Perdue, Peter. "Rethinking the Chinese World Order: Historical Perspectives on the Rise of China." Journal of Contemporary China, forthcoming.

29. Thinh, Ngo Duc. "Lý thuyết trung tâm và ngoại vi trong nghiên cứu không gian văn hóa." (Central and Peripheral Theory in Researching Cul-tural Space) Journal of Social Science Information, No. 3 (2014).

30. Tien, Tran Nam. "Văn hóa ứng xủ của Việt Nam trong quan hệ với Trung Quốc thời trung đại- Nhìn tù hoạt động sắc phong và triều cống (Vietnam's Behavioral Culture in Relations with China in the Medieval Ages - Considered from the "Ordination and tribute)." Science \& Technology Development, Vol. 15, No. X1. (2012)

31. Tung, Nguyen Thanh. Peaceful communication and competition: about the reunion between the Dai Viet envoys and Choson envoys in China in 1766-1767, "International Conference on Vietnam - Korea Relationship in the past, the present and the future (2012)" held by University of Social Sciences and Humanities, Ho Chi Minh City under the sponsorship of the Academy of Korean Studies.

32. Seth, Michael J. A History of Korea: From Antiquity to the Present. Landham, Md.: Rowman \& Littlefield, 2011.

33. Taylor, Keith W. "China and Vietnam: Looking for a New Version of an Old Relationship," in Jayne Werner \& Lưu Đoàn Huynh, The Vietnam War: American and Vietnamese Perspectives, New York: M.E. Sharpe, 1993.

34. Tsuboi, Yoshiharu. Nuoóc Đại Nam đối diện với Pháp vàTrung Hoa 1847-1885 (Dai Nam faced France and China from 1847-1885), Hanoi: Vietnam Historical Society, 1992.

35. Vinh, Nguyen Huy, ed. Thạc Đình di cảo (Thac Dinh posthumous manuscript), Vietnam Library of Institute of Sino-Nom studies, sym- 
bol A.3135, sheet 87a, 2006.

36. Vuong, Tran Quoc. "Tradition, Acculturation, Renovation: The Evolution Pattern of the Vietnamese Culture", in David G. Marr, A. C. Milner. Southeast Asia in the 9th to the 14th Centuries. Singapore: Institute for Southeast Asian Studies, 1988.

37. Vuong, Tran Quoc. "Suy nghĩ đôi điều về văn hóa Việt Nam (Trong sự đối sánh với văn hóa Trung Quốc.” “(Something About Vietnamese Culture (In com-parison with Chinese culture)") in Vietnamese Culture to be Explored and Pondered. Literature Publishing House, 2003.

38. Wei Liang \& Faizullah Khilji. China and East Asia's Post - Crisis Community: A region in Flux. Lexington Books, 2012, Chapter 1.

39. Womack, B. "Asymmetry Theory and China's Concept of Multipolarity." Journal of Contemporary China 13, no. 39 (May 2004):351366. https://doi.org/10.1142/9789814295284_0011

40. Womack, B. "Asymmetry and China's Tributary System." The Chinese Journal of International Politics 5 no. 1 (2012):37-54. https://doi.org/10.1093/cjip/pos003

41. Woodside. Vietnam and the Chinese Model: A Comparative Study of Vietnamese and Chinese Government in the First Half of the Nineteenth Century, Cambridge, Mass.: Harvard University Press, 1971.

42. Yi, Kibaek. A New History of Korea. Harvard University Press, 1984.

43. Yu, Insun. "Lịch sử quan hệ Việt Nam -Trung Quốc thế kỷ XIX. Thể chế triều cống, thực và hư." ("History of Vietnam - China relations in the nineteenth century: Tributary institutions, truths and wrongs") Historical Studies 9 (2009). 
$<$ Abstract $>$

\section{Tributary Activities of Vietnam and Korea with China: Similarities and Differences}

As two countries using China's writing system based on pictographic characters, Korea and Vietnam both maintained tributary relations with China during the pre-modern period. ${ }^{49}$ Compared to other countries in the tributary system, Vietnam and Korea are commonly considered the two archetypal tributary countries. This article examines the common characteristics and the differences in the tributary activities used by these two countries. By considering some aspects of tribute behavior, such as the cause of the tribute, periodicity of tribute, the dispatch of people to pay tribute, characteristics of members of the envoy delegations, the offerings of tribute, and the geographic position of the two countries in the tributary system, this paper describes the typical features of this system and explains the cause for maintaining it for such a long time. This paper also shows the diplomatic behavior of Vietnam - Korea in relations with the dominant neighboring country (China) at that time. These behaviors are still good practices for the two countries in relations with major countries in the region and the world today.

Keywords: Tribute, Vietnam, Korea, China

49 The pre-modern period of Vietnam was from 938 to 1945; meanwhile, the premodern period of Korea was from $57 \mathrm{BC}$ to $1910 \mathrm{AD}$. 
〈국문초록〉

\title{
베트남과 한국의 대(對) 중국 조공 활동: 공통점과 차이점
}

\author{
Nguyen Thi My Hanh (Hanoi National University of Education)
}

상형 문자에 기반을 둔 중국의 문자 체계를 사용하는 두 국가인 한국과 베트남은 전 근대 시기 동안 중국과 조공 관계를 유지했습니다. 조공 체제에 속한 다른 국가들에 비교했을 때, 베트남과 한국 모두 전형적인 조공 국가로 간주됩니다. 이 글은 두 국가 가 시행했던 조공 활동의 공통점과 차이점들을 다루고 있습니다. 조공의 배경과 조공 기간, 조공 사절단의 파견, 사절단 구성원들의 특징, 조공으로 바친 공물들, 그리고 두 국가의 지리적 위치 등과 같은 조공 활동의 몇 가지 양상을 고려하여, 이 글은 조공 관계의 유형적 특성에 대하여 서술하며, 이 체제가 오래 유지될 수 있었던 배경을 설 명하고 있습니다. 이 글은 인접한 강대국인 중국에 대한 베트남과 한국의 전근대 시기 외교를 보여줍니다. 양국의 외교활동에서 발견되는 특징들은 현재 이 지역 그리고 세 계의 주요 국가들과 관계를 맺을 때 양국이 참고할 수 있는 좋은 지침이 될 수 있습니 다.

주제어: 조공, 베트남, 한국, 중국 
